Ann. rheum. Dis. (1964), 23, 73.

\title{
COMPARATIVE STUDY FOR THE DETECTION OF ANTINUCLEAR FACTORS WITH THE FLUORESCENT ANTIBODY TECHNIQUE*
}

\author{
BY \\ W. HIJMANS, H. R. E. SCHUIT, E. MANDEMA, $\uparrow$ R. L. F. NIENHUIS, $\dagger$ \\ T. E. W. FELTKAMP, E. J. HOLBOROW, AND G. D. JOHNSON \\ From the Research Laboratories, Department of Rheumatology, University Hospital, Leyden, the Department \\ of Internal Medicine, University Hospital, Groningen, the Central Laboratory of the Netherlands Red Cross \\ Blood Transfusion Service, Amsterdam, and the Medical Research Council Rheumatism Research \\ Centre, Taplow, England
}

The technique of immunofluorescence for the detection of anti-nuclear factors in human sera has found wide application for diagnostic as well as for research purposes since its introduction by Friou, Finch, and Detre (1957), Holborow, Weir, and Johnson (1957), and Holman and Kunkel (1957). It is generally agreed that this test is positive in almost all patients suffering from systemic lupus erythematosus, and that the incidence of positivity is very low in healthy subjects. The reported figures on the incidence in diseased control groups, however, show such a wide variation (Hijmans, 1963) that it seemed advisable to investigate the possible causes of these discrepancies. To this end a comparative study was undertaken in four laboratories, each of which applied one or more different systems to investigate the presence of anti-nuclear factor(s) (A.N.F.) in the same hundred sera.

\section{Material and Methods}

Human Sera.-Blood was obtained from 100 cases of proven pulmonary tuberculosis of at least 6 months' duration. The data on age and sex are presented in Table I.

TABLE I

SEX AND AGE DISTRIBUTION OF PATIENTS

\begin{tabular}{c|c|c|c}
\hline \multirow{2}{*}{ Sex } & $\begin{array}{c}\text { Number } \\
\text { of } \\
\text { Cases }\end{array}$ & \multicolumn{2}{|c}{ Age (yrs) } \\
\cline { 2 - 3 } & 60 & Range & Mean \\
\hline M & $16-83$ & 51 \\
\hline Total & 40 & $14-73$ & 41 \\
\hline 100 & $14-83$ & 46 \\
\hline
\end{tabular}

* Presented in part before the Fifth European Congress on Rheumatic Diseases, August 25-28, 1963, Stockholm, Sweden.

+ Supported by a grant of the Netherlands Organization for the Advancement of Pure Research (ZWO).
Patients who were also suffering from rheumatoid arthritis or one of the other collagen diseases were excluded. Although the erythrocyte sedimentation rate was normal in most cases (Table II), the disease process could still be considered active from a radiological point of view.

TABLE II

ERYTHROCYTE SEDIMENTATION RATE (WESTERGREN METHOD)

\begin{tabular}{c|c}
\hline Range (mm./1st hr) & Number of Cases \\
\hline $1-5$ & 22 \\
\hline $6-10$ & 26 \\
\hline $11-15$ & 16 \\
\hline $16-20$ & 13 \\
\hline $21-40$ & 17 \\
\hline$>40$ & 6 \\
\hline Total & 100 \\
\hline
\end{tabular}

The sera were stored at $-20^{\circ} \mathrm{C}$. and were kept in the frozen state during transport to the participating laboratories. Examinations were performed not later than 2 years after the samples were obtained.

Substrates. $\ddagger$-Four substrates (A-D) were used: Calf thyroid (A) and mouse liver (D) were taken as fresh frozen tissues from which cryostat sections were prepared. The leucocytes (B) were those present in routine blood smears, and the buccal mucosa cells from healthy volunteers (C) were obtained by scraping with a wooden spatula and were used fresh and unfixed after washing with $0.01 \mathrm{M}$ saline phosphate buffer, $\mathrm{pH} 7$.

Conjugates. + -Five different antisera (l to V), all conjugated with fluorescein isothiocyanate, were used:

I. Horse immune serum against human serum, issued by the Central Laboratory of the Netherlands Red Cross Blood Transfusion Service, absorbed with rabbit liver powder;

\footnotetext{
$\ddagger$ The symbols between brackets refer to those used in the text,
} in Table IV, and in Fig. 1. 
II. Rabbit anti F.II, prepared by injecting rabbits with rabbit red cells coated with human Cohn fraction II and then absorbed with rabbit liver powder;

III. Rabbit immune serum against human serum, absorbed with human liver;

IV. Rabbit anti-human globulin, obtained from Sylvana Chemical Company, Orange, N.Y., Lot No. 1116621, and subsequently absorbed with rat liver;

V. Horse anti-human serum, manufactured by Progressive Laboratories, Inc., obtained from Roboz Surgical Instrument Co., Washington 7, D.C. In this study only Lot No. 3112 was used, and this was absorbed with human liver after neutralization with unconjugated antiserum.

Test Procedures.-The procedures applied were those used routinely in the participating laboratories (Table III). All tests were read without knowledge of the results obtained by the other investigators. In some cases the specificity of the reaction was further investigated by testing with a conjugate previously neutralized with human Cohn fraction II.
Immuno-electrophoresis.-The technique employed was the micromethod of Scheidegger (1955) with barbital buffer, $\mathrm{pH}=8 \cdot 6,0.05 \mathrm{M}$.

$19 S$ Protein.-This fraction was prepared by gradientcentrifugation in sucrose solutions of a serum from a patient suffering from Waldenström's macroglobulinaemia. No line which could be due to the presence of 7S gammaglobulin was observed on immuno-electrophoresis of this fraction.

\section{Results}

The combined results of the tests for the antinuclear factors are presented in Table IV. Positivity ranged from zero to 30 per cent. No positive tests were obtained when calf thyroid tissue was used as a substrate, but these tests were performed with sera in a $1: 10$ dilution. One serum gave a weak positive nuclear staining with Conjugate II. This staining was significantly reduced when the inhibited conjugate was used.

In the test systems with leucocytes (B) nuclear

TABLE III

DETAILS OF TEST PROCEDURE

\begin{tabular}{|c|c|c|c|c|c|c|c|c|}
\hline \multirow[t]{2}{*}{ Laboratory } & \multirow[t]{2}{*}{ Code } & \multirow[t]{2}{*}{ Authors } & \multirow[t]{2}{*}{ Date } & \multirow{2}{*}{ Substrate } & \multicolumn{2}{|c|}{$\begin{array}{c}\text { Incubation Time } \\
\text { (min.) }\end{array}$} & \multirow{2}{*}{$\begin{array}{l}\text { Optical } \\
\text { System }\end{array}$} & \multirow{2}{*}{ Light Source } \\
\hline & & & & & Serum & Antiserum & & \\
\hline Taplow & $(\mathrm{T})$ & Holborow and Johnson & 1964 & Unfixed & 30 & 30 & Cooke & $\begin{array}{l}\text { Mazda ME/D } \\
250 \mathrm{~W} .\end{array}$ \\
\hline Anisterdam & (A) & Feltkamp and Kruyff & 1963 & $\begin{array}{l}\text { Fixed } 30 \mathrm{~min} \text {. in } \\
\text { ethanol } \\
96 \text { per cent. }\end{array}$ & 30 & 30 & Leitz & Philips CS 150W. \\
\hline Groningen & (G) & $\begin{array}{l}\text { Mandema, Pollak, Kark, } \\
\text { and Rezaian }\end{array}$ & 1961 & Unfixed & $90^{*}$ & 30 & $\begin{array}{l}\text { Reichert } \\
\text { Zetopan }\end{array}$ & $\begin{array}{l}\text { Osram HBO } \\
200 \mathrm{~W} .\end{array}$ \\
\hline Leiden & (L) & $\begin{array}{l}\text { Alexander, Bremner, and } \\
\text { Duthie }\end{array}$ & 1960 & Unfixed & $30^{*}$ & 30 & $\begin{array}{l}\text { Leitz } \\
\text { Zeiss }\end{array}$ & $\begin{array}{l}\text { Philips CS } 150 \mathrm{~W} \text {. } \\
\text { Osram HBO } \\
200 \mathrm{~W} \text {. }\end{array}$ \\
\hline
\end{tabular}

* Brought to $37^{\circ} \mathrm{C}$. before application.

RESULTS OF COMPARATIVE STU尹̈Y

The figures in the upper horizontal column refer to the infividu

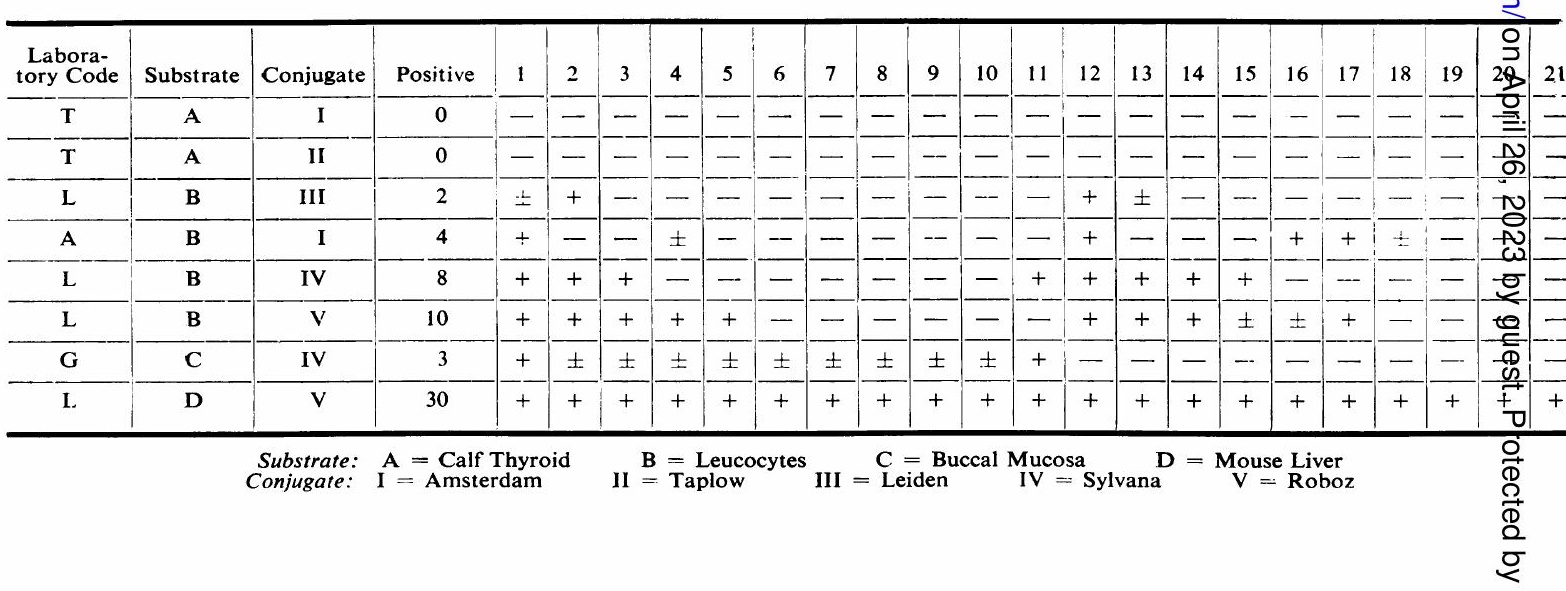


staining was seen with respectively $2,4,8$, and 10 sera, the result depending on the antisera used. These figures were increased to $4,7,8$, and 12 respectively if weak positive reactions were also included.

23 sera reacted with the nuclei of buccal mucosa cells, three were distinctly positive, and twenty weak positive (System C-IV). Only distinctly positives were seen when mouse liver sections were used in combination with the "Roboz" conjugate. The latter system showed nuclear staining in 30 per cent., but this fell to 11 per cent. when human liver sections were used instead of mouse liver, and in combination with Conjugate III there were only two positive sera, irrespective of the source of the liver sections.

In an attempt to investigate the possibility that the conjugated antisera were directed against different immunoglobulins in the sera of the patients, immuno-electrophoresis was carried out with a normal human serum as the antigen source and the conjugate as antiserum (Figure). The immunoelectropherograms showed significant differences: the beta-2 M line was prominent in the Roboz system with an almost complete absence of the $7 \mathrm{~S}$ gamma line. The reverse situation was found with Conjugate III, and Conjugate IV held an intermediate position.

Further evidence that the level of anti beta-2 $\mathbf{M}$ in the conjugate may have been operative in our results was obtained by absorption of Conjugate V. $0.5 \mathrm{ml}$. "Roboz" antiserum was absorbed first with $0.02 \mathrm{ml}$. and the supernatant again with $0.01 \mathrm{ml}$. of a 19S gamma globulin solution containing $7 \mathrm{mg}$. protein per $\mathrm{ml}$. On immuno-electrophoretic analysis the second supernatant no longer formed a beta-2 $\mathrm{M}$

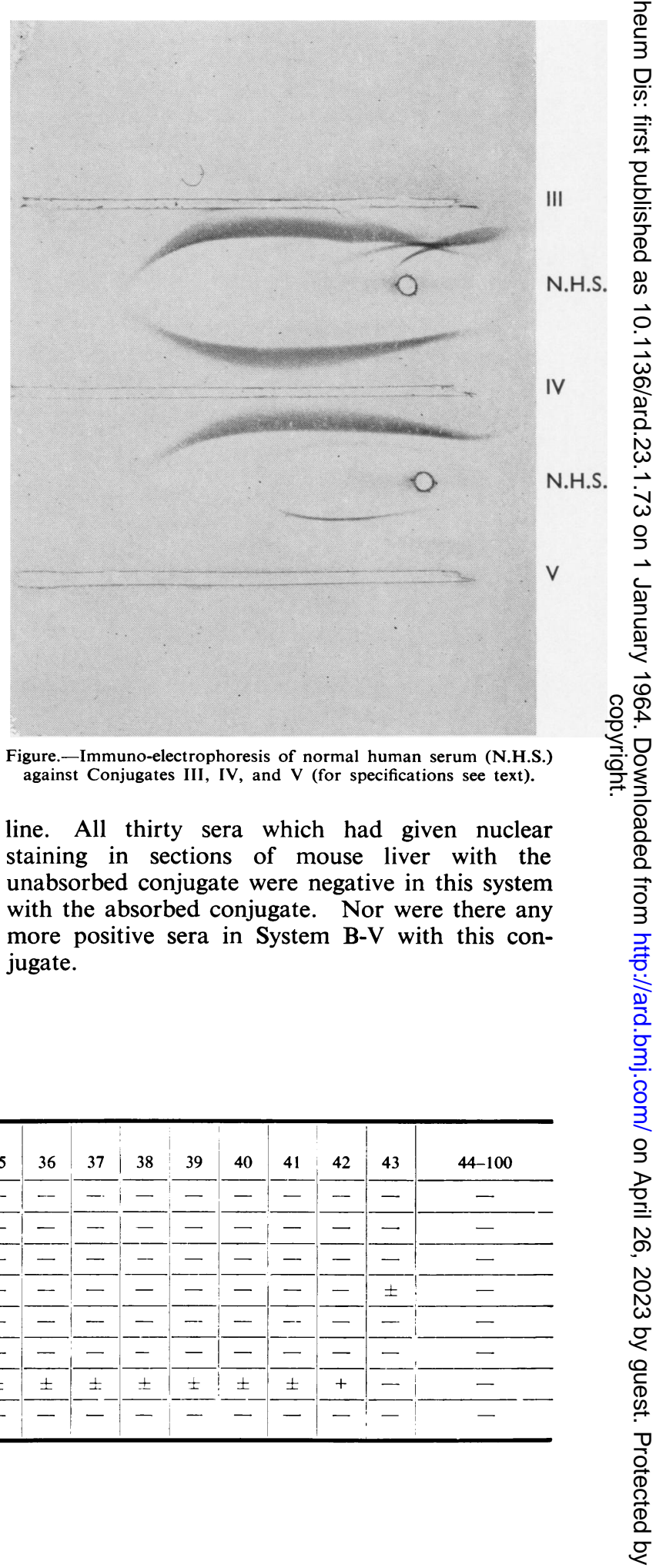

;era. Numbers 44-100 were negative in all systems.

\begin{tabular}{|c|c|c|c|c|c|c|c|c|c|c|c|c|c|c|c|c|c|c|c|c|c|c|}
\hline 22 & 23 & 24 & 25 & 26 & 27 & 28 & 29 & 30 & 31 & 32 & 33 & 34 & 35 & 36 & 37 & 38 & 39 & 40 & 41 & 42 & 43 & $44-100$ \\
\hline - & - & - & - & - & - & - & - & - & - & - & - & - & - & - & - & - & - & - & - & - & - & 一 \\
\hline- & - & - & - & - & - & - & - & - & - & \pm & - & - & - & - & - & - & - & - & - & - & - & - \\
\hline 一 & - & - & - & - & - & - & - & - & - & - & - & - & - & - & - & - & - & - & - & - & - & - \\
\hline - & - & - & - & - & - & - & - & - & - & - & - & - & - & - & - & - & - & - & - & - & \pm & - \\
\hline- & - & - & - & - & - & - & - & - & - & - & - & - & - & - & - & - & - & - & -- & - & - & - \\
\hline - & - & - & - & - & - & - & - & - & + & - & - & - & - & - & - & - & - & - & 一 & - & - & - \\
\hline- & - & - & - & - & - & - & - & - & \pm & \pm & \pm & \pm & \pm & \pm & \pm & \pm & \pm & \pm & \pm & + & - & - \\
\hline+ & + & + & + & + & + & + & + & + & - & - & - & - & - & - & - & - & - & - & - & - & - & - \\
\hline
\end{tabular}


The third approach consisted of dissociation experiments. The thirty positive sera were treated with mercapto-ethanol, $0.01 \mathrm{M}$ final concentration for $3 \mathrm{hrs}$ at $37^{\circ} \mathrm{C}$. and tested on mouse liver with the unabsorbed "Roboz" conjugate. No positive results were obtained with any of these sera after mercapto-ethanol treatment. A control serum from a case of systemic lupus erythematosus with a strongly positive L.E.-cell preparation and A.N.F. test remained positive after the addition of mercaptoethanol.

Differences could also be shown to exist in the substrates. The two sera which were positive in System B-III were absorbed with leucocytes. They were then negative in this system and also when tested with mouse liver and Conjugate III. When, however, Conjugate $\mathrm{V}$ was applied to these absorbed sera with mouse liver as substrate, the nuclear staining was still positive.

\section{Discussion}

In order to analyse the difference in the results obtained when testing for the detection of the presence of anti-nuclear serum factors, 100 sera from patients suffering from pulmonary tuberculosis were investigated by means of the indirect fluorescent antibody technique using different substrates and conjugates.

Although no definite proof has been sought in every individual serum that the component responsible for nuclear staining is an antibody, there is satisfactory overall evidence that such is indeed the case. Where tested these factors were found to be heat-stable and to react with anti-human globulin serum. In one case in which this was investigated, the reaction could be inhibited by a human Cohn fraction II and, when these factors were presumed to be of the macroglobulin type, a positive result could be reversed by treatment with mercaptoethanol. It therefore seems justifiable to discuss the problems of this comparative study in terms of antigen-antibody interactions.

By applying a system with calf thyroid as a substrate, sera diluted $1: 10$, and a horse immune serum against human serum conjugated with isothiocyanate, no nuclear staining was seen (A-I and A-II). The other extreme was formed by the system, using mouse liver and a conjugate obtained from Roboz Surgical Instrument Co., whereby thirty positive sera were encountered (D-V). Various results were obtained between these two limits.

This large variation cannot be due solely to differences in the sensitivity of the various systems, because in most series there were one or more positive sera which were negative in a system with a higher incidence of positivity. One of the two positive sera in System B-III was negative in System B-I, and if the weak positive results are also included, two out of four were negative. The same general conclusion can be drawn from the comparison of the other combinations (Table IV).

There are many arguments in favour of the hypothesis that different antibodies are involved in the sera and in the conjugates. These differences also extond to the tissue level, where several antigens may be present or antigenic determinants be available, depending on the condition of the substrate. The qualitative differences between the various substrates become clear in the comparison of paired series where the same conjugate was applied. Four of the eight sera which were positive in System B-IV were negative in System C-IV. One positive serum in System B-V was negative in System D-V. Five positive sera in system B-I were all negative in System A-I, although the restriction should be made that in the latter series the sera were diluted $1: 10$.

The existence of different serum factors with nuclear affinity has been known since the publications by Goodman, Fahey, Malmgren, and Brecher (1959), and Goodman, Fahey, and Malmgren (1960), who were able to separate two types of immunoglobulins, one a 7S component and the other aco macroglobulin, both of which gave nuclear staining. In our study this heterogeneity was also shown to be present. Treatment of the sera with mercaptoethanol reversed the positive reactions of all thirty sera in System D-V, but the two sera which were originally positive in System B-III did not become negative in the other system, although the intensity of the staining was decreased considerably by this treatment. Further investigations of the conjugates supported these findings. Conjugate $\mathrm{V}$ especially had a strong anti-beta-2 $\mathbf{M}$ activity, as shown by immuno-electrophoresis, and when this conjugate had been absorbed with a purified 19S globulin fraction no more nuclear fluorescence could be detected with either liver or leucocytes (B-V and D-V).

From these studies it may be concluded that at least two different antigen-antibody systems can give rise to nuclear staining. The total number of different antigens and antibodies involved cannot be stated without further analysis. Nor is it possible to state which system should be preferred, because this choice will depend on the purpose of the test. It is obvious that a high incidence in a control group will be unsatisfactory for diagnostic purposes, but such a situation does not necessarily preclude the application of this 
method in epidemiological studies, because the genetic characteristics can express themselves through one or the other of the various serum antibodies. Furthermore, it is possible to determine the titre of these factors. If this immunofluorescent test is to be used as a screening procedure for the L.E.-cell test, a conjugate should be chosen which interacts with the 7S gammaglobulin, because it is known that the L.E.-cell factor belongs to this class of immunoglobulins.

No mention has so far been made of the role that the different optical systems could play in explaining the great variation in the results. Although no systematic analysis has been performed to analyse this role, it seems unlikely that it plays anything but a minor part. In one laboratory (L), two sets were routinely available and no discrepancy in the results could ever be attributed to the use of one or the other of these two microscopes of different make.

Finally, it should be noted that, in any comparative study of this kind, one should not only assess the overall outcome but also take the individual results into consideration. Four sera were positive in System B-I; in the same laboratory (A) four sera were positive when these sera were investigated in an additional study for the presence of A.N.F. with human thyroid sections as substrate and a conjugated antiserum prepared according to Milgrom, Luszczynski, and Dubiski (1956); only one sample was found to be positive in both systems.

\section{Summary}

A comparative study was carried out to investigate the influence of a number of variables on the detection of anti-nuclear factors in human sera. The indirect immunofluorescent test was applied throughout, using a number of different substrates and antisera, conjugated with isothiocyanate. Positive results were obtained in 0 to 30 per cent. in a series of 100 sera obtained from patients suffering from pulmonary tuberculosis. It could be shown that the discrepancies were due not only to quantitative differences in the sensitivity of the techniques but also to the presence of various antigen-antibody systems.

The authors gratefully acknowledge the advice and assistance received from Mr. F. Klein.

\section{REFERENCES}

Alexander, W. R. M., Bremner, J. M., and Duthie, J. J. R. (1960). Ann. rheum. Dis., 19, 338.

Feltkamp, T. E. W., and Kruyff, K. (1963). Vox Sang. (Basel), 8, 302.

Friou, G. J., Finch, S. C., and Detre, K. D. (1957). Fed. Proc., 16, 413.

Goodman. H. C., Fahey, J. L., and Malmgren, R. A. (1960). J. clin. Invest., 39, 1595.

,$--\longrightarrow$, and Brecher, G. (1959). Lancet, 2, 382.

Hijmans, W. (1963). In "The Epidemiology of Chronic Rheumatism", ed. J. H. Kellgren, vol. 1, p. 82. Blackwell Scientific Publications, Oxford.

Holborow, E. J., and Johnson, G. D. (1964). To be published.

-, Weir, D. M., and Johnson, G. D. (1957). Brit. med. J., 2, 732 .

Holman, H. R., and Kunkel, H. G. (1957). Science, 126, 162 .

Mandema, E., Pollak, V. E., Kark, R. M., and Rezaian, J. (1961). J. Lab. clin. Med., 58, 337.

Milgrom, F., Luszczynski, T., and Dubiski, S. (1956). Nature (Lond.), 177, 329.

Scheidegger, J. J. (1955). Int. Arch. Allergy, 7, 103.

Etude comparée de la recherche des facteurs antinucléaires par le procédé d'immunofluorescence

RÉSUMÉ

On étudia l'influence d'un certain nombre de variables sur la recherche des facteurs antinucléaires dans les sérums humains. Invariablement on employa la réaction d'immunofluorescence indirecte, tout en changeant les substrata et les anti-sérums, conjugués à l'isothiocyanate. Des résultats positifs furent obtenus en $\mathbf{0}$ à $\mathbf{3 0}$ pour cent dans une série de 100 sérums provenant des malades atteints de tuberculose pulmonaire. On peut démontrer que ces divergences ne sont pas dues seulement aux différences quantitatives dans la sensibilité des procédés, mais aussi à la présence de différents systèmes d'antigène-anticorps.

Estudio comparativo de la detección de los factores antinucleares por el procedimiento de inmunofluorescencia

\section{SUMARIO}

Se llevó a cabo un estudio comparativo de la influencia de un cierto número de variables en la detección de los factores antinucleares en los sueros humanos. En todos los casos se empleó la reacción de inmunofluorescencia indirecta, cambiando los substrata y los antisueros conyugados con isotiocianato. Resultados positivos fueron obtenidos en un 0 a 30 por ciento de una serie de 100 sueros de enfermos con tuberculosis pulmonar. Se puede ver que estas divergencias se debieron no sólo a diferencias cuantitativas en la sensibilidad de los procedimientos sino tambtén a la presencia de varios sistemas de antigen-anticuerpo. 